ISSN 0258-7122 (Print), 2408-8293 (Online)

Bangladesh J. Agril. Res. 44(1): 179-193, March 2019

\title{
EFFECT OF HARVESTING DATES ON THE YIELD AND TUBER QUALITY OF PROCESSING POTATOES
}

\author{
M. SHARKAR ${ }^{1}$, J. U. AHMED ${ }^{2}$, S. F. AHMED ${ }^{3}$ \\ S. M. Z. AL-MERAJ ${ }^{4}$ AND M. MOHI-UD-DIN ${ }^{5 *}$
}

\begin{abstract}
An experiment was conducted to study the effect of harvesting dates and variety on the yield and processing quality of potato tuber. Three processing potato varieties (BARI Alu-25, Asterix; BARI Alu-28, Lady Rosetta and BARI Alu-29, Courage) were used as test crops and they were harvested at different days after planting [80, 90, and 100 days after planting (DAP)]. The three processing potato varieties showed higher tuber yield of Grade A $\left(9.12 \mathrm{t} \mathrm{ha}^{-1}\right)$ and B (13.64 $\left.\mathrm{t} \mathrm{ha}^{-1}\right)$. The highest tuber yield (Grade $\left.\mathrm{A}+\mathrm{B}\right)\left[29.62 \mathrm{t} \mathrm{ha}^{-1}\right]$ and total tuber yield (35.97 $\mathrm{t} \mathrm{ha}^{-1}$ ) was found in Courage at 90 and 100 DAP harvest, respectively. The variety Lady Rosetta attained the highest percent of processable tuber yield ( $86.8 \%$ of the total tuber yield), the maximum dry matter content $(26.37 \%)$, specific gravity (1.102) at 90 DAP harvest and this variety also contained the highest mean starch content $\left(111.75 \mathrm{mg} \mathrm{g}^{-1} \mathrm{FW}\right)$ followed by Courage $(111.17$ $\mathrm{mg} \mathrm{g}^{-1} \mathrm{FW}$ ) and Asterix (103.95 $\left.\mathrm{mg} \mathrm{g}^{-1} \mathrm{FW}\right)$. Optimum dry matter content (24.07\%), specific gravity (1.091), starch content (110.15 $\left.\mathrm{mg} \mathrm{g}^{-1} \mathrm{FW}\right)$, processable tuber yield $\left(26.62 \mathrm{t} \mathrm{ha}^{-1}\right)$ and total tuber yield $\left(32.76 \mathrm{t} \mathrm{ha}^{-1}\right)$ was found at 90 DAP harvest and therefore, it could be mentioned as suitable harvesting date for processing purposes. Among the varieties, Lady Rosetta and Courage were found preferable potato varieties that could be used for processing of potato products.
\end{abstract}

Key words: Potato, processable yield, tuber yield, dry matter and starch.

\section{Introduction}

Potato (Solanum tuberosum L.) is one of the most important vegetable crop and it is a part of daily food utilization of almost all the world population (Mathur, 2003). Bangladesh is the world's seventh largest producer of potatoes with a total production of about 10.21 million tons (BBS, 2017). It is consumed in different forms like boiled or fried and many different processed products such as chips, French fries, powder, potato papad etc. which are enjoyed across the generations and continents. Processing quality of potato tubers is determined by high dry matter and low reducing sugar and phenol contents (Kadam et al., 1991). High

\footnotetext{
${ }^{1}$ MS student, Dept. of Crop Botany, Bangabandhu Sheikh Mujibur Rahman Agricultural University (BSMRAU), ${ }^{2}$ Professor, Dept. of Crop Botany, BSMRAU, ${ }^{3}$ Graduate student, Dept. of Crop Botany, BSMRAU, ${ }^{4}$ Assistant Professor, Dept. of Crop Botany, BSMRAU, ${ }^{5 *}$ Associate Professor, Dept. of Crop Botany, BSMRAU, Bangladesh.
} 
dry matter content increases chip yield, crispy-consistency and reduces oil absorption during cooking (Pedreschi et al., 2005; Rommens et al., 2010).

Meeting the increasing demand and quality of the end products of potato processing industries depend mostly on production capacity of quality tubers. Moreover, a grading system, one popular approach for determining properties and minimizing the risk of marketing of the produce, can be easily utilized to ensure quality tubers for fresh dishes as well as processing industries. However, quality of these processed food products mainly depends on tuber inherent characteristics, growing conditions, maturity, dry matter, starch content, specific gravity, low fat and sugars etc. (Kumar et al., 2011; Buono et al., 2009).

Though dry matter and starch contents of potato affect mainly texture and nutritional value of the tubers, in addition to tuber chemical composition, texture of processed food products is affected also by the degree of tuber maturity (Murniece et al., 2010). It has been revealed by many efforts that yield of potato tubers along with their external and internal characteristics are influenced by different factors such as soil type, fertilizers application, dates of planting and harvesting in addition to their genetic factor (Hamouz et al., 2005; Herman et al., 1996). According to Rytel (2004) and Lisińska (2006), delayed harvest results in increased starch and dry matter contents of potato but their accumulation depends on cultivar and growing conditions. Among the agricultural practices, total crop duration or harvesting time had the prominent effects on total yield and nutritional composition of crop plants so, it is necessary to collect the produce at its proper growth stage.

Considering above facts, the present study was initiated to determine appropriate harvesting date and processing variety of potatoes regarding yield and tuber quality.

\section{Materials and Methods}

The experiment was conducted at Bangabandhu Sheikh Mujibur Rahman Agricultural University (BSMRAU), Gazipur, which is located at the center of Madhupur Tract $\left(24^{\circ} 05^{\prime} \mathrm{N}\right.$ latitude and $90^{\circ} 25^{\prime} \mathrm{E}$ longitude) at an elevation of 8.4 $m$ above the sea level. BARI Alu-25 (Asterix), BARI Alu-28 (Lady Rosetta) and BARI Alu-29 (Courage) were used as plant materials and they were harvested at different days after planting [80, 90, and 100 days after planting (DAP)]. Here, three processing potato varieties represent Factor A and harvesting dates of 80, 90, and 100 DAP represent Factor B. The experiment was laid out in a factorial RCBD design with 4 replications.

The processing potato seed tubers were planted in $4 \mathrm{~m} \times 3 \mathrm{~m}$ plot using $60 \mathrm{~cm} \times 25 \mathrm{~cm}$ spacing at the end of November and sixteen seed tubers were placed in every row. The crop was raised as per the recommended cultural practices for the Modhupur Tract region. A fertilizer dose of N, P, K and S was applied as per 
fertilizer recommendation guide in the form of Urea, Triple Supper Phosphate (TSP), Muriate of potash (MP), Gypsum, respectively along with cow dung. Full doses of cow dung (10 t ha-1), TSP (150 kg ha-1), MP (250 kg ha-1), Gypsum (120 $\left.\mathrm{kg} \mathrm{ha}{ }^{-1}\right)$, and half doses of Urea $\left(125 \mathrm{~kg} \mathrm{ha}^{-1}\right)$ were applied at final land preparation. The rest half doses of Urea were applied as top dressing at 30 DAP followed by earthing up and light irrigation. Irrigation was applied five times. First one was given just after planting while the rest irrigation was applied at 20, 30, 40, and 50 DAP. Earthing up was done in two times during growing period. First earthing up was done at 30 DAP when the plant attained a height of about $15-20 \mathrm{~cm}$ while the last one was done after 20 days of first earthing up. Ridomil Gold was sprayed at the rate of $5 \mathrm{~g} \mathrm{~L}^{-1}$ once after rainfall to prevent the late blight disease of potato. The haulms were cut at 70,80 , and 90 DAP. Tubers were harvested 10 days after haulm cutting.

Data were recorded on the yield of different grades tuber, processable tuber yield, total tuber yield, dry matter content, specific gravity and starch content of the test varieties. The chemical analysis was done in the Crop Botany Laboratory of BSMRAU.

\section{Grading of potato tubers}

After harvesting potato tubers were classified into four grades according to Karim et al. (2010), estimating diameter at the middle of the potato tubers. The grades were i) Under grade $(<28 \mathrm{~mm})$, ii) Grade A $(28-40 \mathrm{~mm})$, iii) Grade B (41$55 \mathrm{~mm}$ ), and iv) Over grade (>55 mm). Among these grades, Grade A and Grade $\mathrm{B}$ together was considered as processable grade tuber.

\section{Determination of tuber dry matter (\%) and specific gravity}

For dry matter content estimation, five tubers were chopped in thin pieces and about $50 \mathrm{~g}$ fresh sample were oven dried at $80^{\circ} \mathrm{C}$ till constant weight was achieved. Then the moisture percentage was determined and this was deducted from the total $100 \%$ moisture to get the dry matter (\%). Specific gravity was determined according to Schippers (1976).

\section{Extraction and determination of starch}

Following the procedure of Kang et al. (2009), potato flesh was extracted using $80 \%$ ethanol at $80^{\circ} \mathrm{C}$ for $30 \mathrm{~min}$ at first and then extracts were centrifuged at $5000 \mathrm{~g}$ for $10 \mathrm{~min}$. Same procedure was repeated for two times taking the supernatants. The remaining residue was washed several times with water to remove soluble sugars remaining in the residue. Then it was dried overnight, added with distilled water and heated in a boiling water bath for $30 \mathrm{~min}$ while stirring on the super mixture several times to gelatinize the starch released from the sample. Eventually, 52\% (v/v) perchloric acid, $6 \mathrm{ml}$ of distilled water was added, and after centrifugation at $4000 \mathrm{~g}$ for $20 \mathrm{~min}$, the supernatant was 
collected in a test tube. This acid hydrolysis was repeated once again and the volume of the supernatants was made up to $50 \mathrm{ml}$ with distilled water into a volumetric flask.

One $\mathrm{ml}$ of aliquot was mixed with distilled water and anthrone reagent, and boiled for $15 \mathrm{~min}$. After cooling for $10 \mathrm{~min}$ in the dark, the absorbance was read at $620 \mathrm{~nm}$. Standard solutions of starch were tested in a same way to obtain a calibration curve. A series of standard solution $(0,62.5,125,250,500,1000 \mu \mathrm{g}$ $\mu \mathrm{l}^{-1}$ starch) was made using starch for the preparation of standard curve.

\section{Statistical analysis}

The analysis of variance for various parameters of potato was performed following ANOVA Technique. When $\mathrm{F}$ was significant at the $\mathrm{p} \leq 0.05$ level, treatment means were separated using DMRT. Data were reported as mean \pm standard error (SE).

\section{Results and Discussion}

Data collected during the experiment were subjected to two factor analysis of variance (ANOVA). The ANOVA for yield data showed that the main effects of the varieties were insignificant except over grade yield, dry matter, specific gravity and starch content (Table 1).

But the main effect of days to harvest were significant for all the parameters except over grade yield. Two-way interaction between the varieties and days to harvest was significant for dry matter and starch content only and the rest others were found insignificant (Table 1).

Table 1. Source of variance and their effect on yield of different grades, processable tuber grades, total tubers, dry matter, specific gravity and starch content of the potatoes

\begin{tabular}{|c|c|c|c|c|c|c|c|c|c|c|}
\hline \multirow{2}{*}{$\begin{array}{l}\text { Source } \\
\text { of } \\
\text { variation }\end{array}$} & \multirow{2}{*}{$\begin{array}{l}\text { Degrees } \\
\text { of } \\
\text { freedom }\end{array}$} & \multicolumn{8}{|c|}{ Mean Squares } & \multirow[b]{2}{*}{$\begin{array}{l}\text { Starch } \\
\text { content }\end{array}$} \\
\hline & & $\begin{array}{l}\text { Under } \\
\text { grade }\end{array}$ & $\begin{array}{c}\text { Grade } \\
\text { A }\end{array}$ & $\begin{array}{c}\text { Grade } \\
\text { B }\end{array}$ & $\begin{array}{l}\text { Over } \\
\text { grade }\end{array}$ & $\begin{array}{c}\text { Processable } \\
\text { yield }\end{array}$ & $\begin{array}{l}\text { Total } \\
\text { yield }\end{array}$ & $\begin{array}{c}\text { Dry } \\
\text { matter } \\
(\%)\end{array}$ & $\begin{array}{l}\text { Specific } \\
\text { gravity }\end{array}$ & \\
\hline $\begin{array}{l}\text { Variety } \\
\text { (V) }\end{array}$ & 2 & 6.89 & 15.42 & 2.10 & $48.90^{*}$ & 8.80 & 17.51 & $72.27^{* *}$ & $\begin{array}{l}1.16 \times \\
10^{-3 * * *}\end{array}$ & $226.45^{* *}$ \\
\hline $\begin{array}{l}\text { Harvest } \\
\text { date } \\
\text { (HD) }\end{array}$ & 2 & $15.13^{*}$ & $66.48^{* *}$ & $55.53^{* *}$ & 12.10 & $241.08^{* * *}$ & $493.93^{* *}$ & $18.28^{* *}$ & $\begin{array}{l}5.72 \times \\
10^{-4 * * *}\end{array}$ & $128.76^{* *}$ \\
\hline $\mathrm{V} \times \mathrm{HD}$ & 4 & 0.84 & 7.79 & 9.52 & 3.19 & 33.02 & 43.58 & $5.26^{*}$ & $3.85 \times 10^{-5}$ & $193.91^{* *}$ \\
\hline Error & 24 & 3.03 & 9.38 & 18.50 & 11.18 & 29.09 & 60.63 & 1.92 & $3.50 \times 10^{-5}$ & 22.87 \\
\hline
\end{tabular}

*indicates significant at $\mathrm{p} \leq 0.05 ; * *$ indicates significant at $\mathrm{p} \leq 0.01$ 


\section{Yield of different grade tubers}

Under grade $(<28 \mathrm{~mm})$ tuber yield increased with crop maturity in all varieties, but the increment was significant only in variety Lady Rosetta between 80 and 100 DAP harvest (Table 2). Lowest mean tuber yield $\left(1.97 \mathrm{t} \mathrm{ha}^{-1}\right)$ was found in the variety Courage followed by Asterix $\left(2.91 \mathrm{t} \mathrm{ha}^{-1}\right)$ and Lady Rosetta $(3.24 \mathrm{t} \mathrm{ha}$ $\left.{ }^{1}\right)$ but their difference was not significant. 80 DAP harvest $\left(1.73 \mathrm{t} \mathrm{ha}^{-1}\right)$ and 90 DAP harvest $\left(2.49 \mathrm{t} \mathrm{ha}^{-1}\right)$ gave significantly lower under grade tuber yield than 100 (3.90 tha ha DAP harvest. Here, Courage gave the lowest percent $(5.40 \%)$ of under grade $(<28 \mathrm{~mm})$ tuber yield of total tuber yield at 90 DAP harvest (Fig. 1).

In Grade A $(28-40 \mathrm{~mm})$, the highest tuber yield $\left(12.12 \mathrm{t} \mathrm{ha}^{-1}\right)$ was found in Courage and Lady Rosetta at 90 DAP harvest (Table 2). The lowest tuber yield $\left(4.95 \mathrm{t} \mathrm{ha}^{-1}\right.$ ) was recorded in Asterix harvested at $80 \mathrm{DAP}$. The result of $90 \mathrm{DAP}$ and 100 DAP harvest was statistically similar but their difference with 80 DAP harvest was significant in case of all varieties (Table 2). Among the varieties, the highest mean yield was achieved by Courage $\left(10.05 \mathrm{tha}^{-1}\right)$ followed by Lady

Table 2. Yield of different grades of potato tuber as influenced by variety and different harvesting dates

\begin{tabular}{|c|c|c|c|c|}
\hline \multirow{2}{*}{ Variety } & \multicolumn{4}{|c|}{ Yield $\left(\mathrm{t} \mathrm{ha}^{-1}\right)$} \\
\hline & $80 \mathrm{DAP}$ & 90 DAP & 100 DAP & Mean \\
\hline \multicolumn{5}{|c|}{ Under grade $(<28 \mathrm{~mm})$} \\
\hline Asterix & $1.97 \pm 0.72^{\mathrm{b}}$ & $2.65 \pm 0.72^{\mathrm{b}}$ & $4.12 \pm 1.61^{\mathrm{ab}}$ & $2.91 \pm 0.63^{\mathrm{A}^{\prime}}$ \\
\hline Courage & $1.39 \pm 0.49^{b}$ & $1.83 \pm 0.26^{\mathrm{b}}$ & $2.69 \pm 0.6^{\mathrm{ab}}$ & $1.97 \pm 0.38^{\mathrm{A}^{\prime}}$ \\
\hline Lady Rosetta & $1.83 \pm 0.35^{\mathrm{b}}$ & $2.99 \pm 0.83^{\mathrm{ab}}$ & $4.89 \pm 1.40^{\mathrm{a}}$ & $3.24 \pm 0.89^{\mathrm{A}^{\prime}}$ \\
\hline Mean & $1.73 \pm 0.175^{\mathrm{B}}$ & $2.49 \pm 0.343^{\mathrm{B}}$ & $3.90 \pm 0.645^{\mathrm{A}}$ & 2.71 \\
\hline \multicolumn{5}{|c|}{ Grade A (28-40mm) } \\
\hline Asterix & $4.95 \pm 1.24^{\mathrm{d}}$ & $9.25 \pm 1.86^{\mathrm{a}-\mathrm{d}}$ & $8.36 \pm 2.40^{\mathrm{a}-\mathrm{d}}$ & $7.52 \pm 1.31^{\mathrm{A}^{\prime}}$ \\
\hline Courage & $6.07 \pm 0.69^{\mathrm{cd}}$ & $12.12 \pm 1.61^{\mathrm{a}}$ & $11.95 \pm 1.55^{\mathrm{ab}}$ & $10.05 \pm 1.99^{\mathrm{A}^{\prime}}$ \\
\hline Lady Rosetta & $7.01 \pm 0.70^{\mathrm{bcd}}$ & $12.12 \pm 1.37^{\mathrm{a}}$ & $10.20 \pm 2.13^{\mathrm{abc}}$ & $9.77 \pm 1.49^{\mathrm{A}^{\prime}}$ \\
\hline Mean & $6.01 \pm 0.594^{\mathrm{B}}$ & $11.16 \pm 0.955^{\mathrm{A}}$ & $10.17 \pm 1.036^{\mathrm{A}}$ & 9.12 \\
\hline \multicolumn{5}{|c|}{ Grade B (41-55mm) } \\
\hline Asterix & $11.63 \pm 1.46^{\mathrm{a}}$ & $14.60 \pm 2.81^{\mathrm{a}}$ & $13.69 \pm 2.65^{\mathrm{a}}$ & $13.31 \pm 0.88^{\mathrm{A}^{\prime}}$ \\
\hline Courage & $10.76 \pm 2.59^{\mathrm{a}}$ & $17.50 \pm 2.11^{\mathrm{a}}$ & $16.79 \pm 2.59^{\mathrm{a}}$ & $15.02 \pm 2.14^{\mathrm{A}^{\prime}}$ \\
\hline Lady Rosetta & $9.63 \pm 2.23^{\mathrm{a}}$ & $14.27 \pm 1.87^{\mathrm{a}}$ & $13.92 \pm 1.86^{\mathrm{a}}$ & $12.61 \pm 1.49^{\mathrm{A}^{\prime}}$ \\
\hline Mean & $10.67 \pm 0.579^{\mathrm{B}}$ & $15.46 \pm 1.023^{\mathrm{AB}}$ & $14.80 \pm 0.997^{\mathrm{A}}$ & 13.64 \\
\hline \multicolumn{5}{|c|}{ Over Grade (>55mm) } \\
\hline Asterix & $3.79 \pm 0.77^{\mathrm{ab}}$ & $6.59 \pm 3.19^{\mathrm{a}}$ & $6.09 \pm 2.94^{\mathrm{ab}}$ & $5.49 \pm 0.86^{\mathrm{A}^{\prime}}$ \\
\hline Courage & $2.66 \pm 0.52^{\mathrm{ab}}$ & $3.30 \pm 0.70^{\mathrm{ab}}$ & $4.54 \pm 1.43^{\mathrm{ab}}$ & $3.50 \pm 0.55^{\mathrm{AB}^{\prime}}$ \\
\hline Lady Rosetta & $0.65 \pm 0.37^{b}$ & $1.05 \pm 0.41^{\mathrm{ab}}$ & $2.71 \pm 0.87^{\mathrm{ab}}$ & $1.47 \pm 0.63^{\mathrm{B}^{\prime}}$ \\
\hline Mean & $2.37 \pm 0.919^{\mathrm{A}}$ & $3.65 \pm 1.609^{\mathrm{A}}$ & $4.44 \pm 0.976^{\mathrm{A}}$ & 3.49 \\
\hline
\end{tabular}

Mean $( \pm$ SE) was calculated from four replicates for each treatment. Values in a column and rows with different small letter(s) are significantly different at $\mathrm{P}=0.05$ by DMRT. Different capital letters beside the mean values are significantly different at $\mathrm{P}=0.05$ by DMRT 
Rosetta $\left(9.77 \mathrm{t} \mathrm{ha}^{-1}\right)$ but the difference was not significant. Considering the harvest mean, 90 DAP $\left(11.16 \mathrm{t} \mathrm{ha}^{-1}\right)$ and 100 DAP $\left(10.17 \mathrm{t} \mathrm{ha}^{-1}\right)$ gave significantly higher Grade A tuber yield than 80 DAP harvest $\left(6.01 \mathrm{t} \mathrm{ha}^{-1}\right)$ (Table 2). At 90 DAP harvest, the variety Lady Rosetta produced the highest percent (39.93\%) of Grade A tuber (Fig. 1).

In Grade B (41-55 mm), the highest yield was obtained at 90 DAP harvest in all 3 varieties but there was no significant difference among their results (Table 2). Varietal means of grade B yield showed that Courage had the highest yield $\left(15.02 \mathrm{t} \mathrm{ha}^{-1}\right)$ as compared to Asterix $\left(13.31 \mathrm{t} \mathrm{ha}^{-1}\right)$ and Lady Rosetta $(12.61 \mathrm{t} \mathrm{ha}$ 1) (Table 2). The highest mean Grade B tuber yield of three harvesting dates reveals that 90 DAP harvest $\left(15.46 \mathrm{t} \mathrm{ha}^{-1}\right)$ was the highest and it had no significant difference with $100\left(14.80 \mathrm{t} \mathrm{ha}^{-1}\right)$ DAP harvest but significantly different from 80 DAP harvest $\left(10.67 \mathrm{t} \mathrm{ha}^{-1}\right)$ (Table 2). Here Lady Rosetta $(56.79 \%)$ gave the highest percent of Grade B tuber yield of total tuber yield at 100 DAP harvest (Fig. 1).

Over grade $(>55 \mathrm{~mm})$ tuber yield increased with crop maturity (Table 2). Lowest tuber yield $\left(0.65 \mathrm{t} \mathrm{ha}^{-1}\right)$ was found in the Lady Rosetta followed by Courage (2.66 $\left.\mathrm{t} \mathrm{ha}^{-1}\right)$ and Asterix $\left(3.79 \mathrm{t} \mathrm{ha}^{-1}\right)$ at 80 DAP harvest.

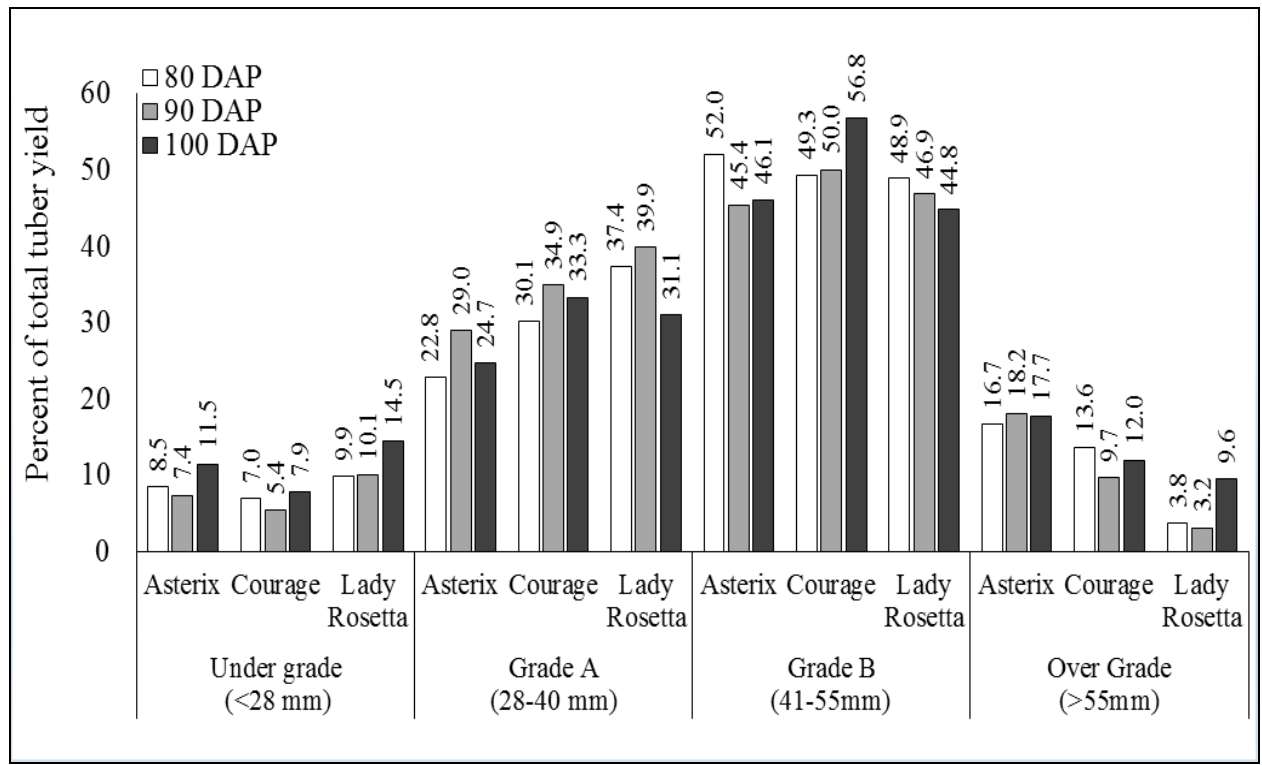

Fig. 1. Percent yield of different grades of potato processing varieties at respective harvesting dates. DAP- Days after planting.

Mean over grade $(<55 \mathrm{~mm})$ tuber yield also increased with crop maturity (Table 2). Lowest mean tuber yield $\left(1.47 \mathrm{t} \mathrm{ha}^{-1}\right)$ was obtained in the Lady Rosetta followed by Asterix (5.49 $\mathrm{t} \mathrm{ha}^{-1}$ ) and Courage (3.50 t ha $\mathrm{ha}^{-1}$ ) and the result of Courage and Lady Rosetta is statistically similar but Lady Rosetta had 
significant difference with Asterix (Table 2). Lady Rosetta (3.15\%) gave the lowest percent over grade tuber yield of total tuber yield at 90 DAP harvest (Fig. 1). Results of the study showed differences in tuber grading of three potato varieties. The effects of heredity were also found significant on potato grading by Muthuraj et al. (2005). Among the tuber grades medium and large tubers are the most prized in fresh tubers market due to peeling facilitation on both domestic and processing purposes. For chips and French frying process, round or oval round form of tuber is preferable besides larger size for commercial standards (Pádua et al., 2012) that suits the present findings where medium to large tubers yielded significantly higher than under and over grade potatoes at 90 DAP harvest.

\section{Processable tuber yield}

Processable tuber (Grade A+B) yield was increased with the maturity up to 90 DAP afterwards it was decreased slightly at 100 DAP in all 3 varieties (Fig. 2). The increment was significant in case of variety Courage and Lady Rosetta. 90 DAP; harvest showed the highest processable tuber yield in all three varieties. The highest processable tuber yield was found in Courage $\left(29.62 \mathrm{t} \mathrm{ha}^{-1}\right)$ at 90 DAP followed by Lady Rosetta $\left(26.39 \mathrm{t} \mathrm{ha}^{-1}\right)$. At 90 DAP harvest, the highest processable tuber yield of Courage $\left(29.62 \mathrm{t} \mathrm{ha}^{-1}\right)$ was found as $85.2 \%$ of total tuber yield of that variety followed by $26.39 \mathrm{t} \mathrm{ha}^{-1}$ in Lady Rosetta $(86.7 \%$ of total tuber yield) and $23.86 \mathrm{t} \mathrm{ha}^{-1}$ in Asterix (72.1\% of total tuber yield) at same harvesting date (Fig. 2).

Irrespective of harvesting time, the varietal mean values did not show any significant difference among them (Fig. 2). Courage had the highest processable tuber yield $\left(25.07 \mathrm{t} \mathrm{ha}^{-1}\right)$ followed by Lady Rosetta $\left(22.38 \mathrm{t} \mathrm{ha}^{-1}\right)$ and Asterix $\left(20.83 \mathrm{tha}^{-1}\right)$.

Mean values of harvesting dates exhibited that 90 DAP gave higher processable tuber yield (81.3\%) than 80 DAP (80.3\%) and 100 DAP harvest (75.0\%) (Fig. 2) but the processable tuber yield of 90 and 100 DAP harvest was statistically similar. Results of the processable tuber yield reveals that 90 DAP harvest is better than 80 and 100 DAP harvest for producing potato yield of suitable sizes. For chips production, round or oval tubers of 35 to 65 $\mathrm{mm}$ sizes having higher dry matter (21-25\%) and starch content (16-20\%) were emphasized by many research efforts (Lisinska, 2006; Zgorska and Frydecka-Mazurczyk, 2002) that justifies the result of present experiment yielding high amount of Grade A and Grade B (processable) potato tubers. It might be the impact of rapid plant emergence and better plant growth (Patel et al., 2008). 


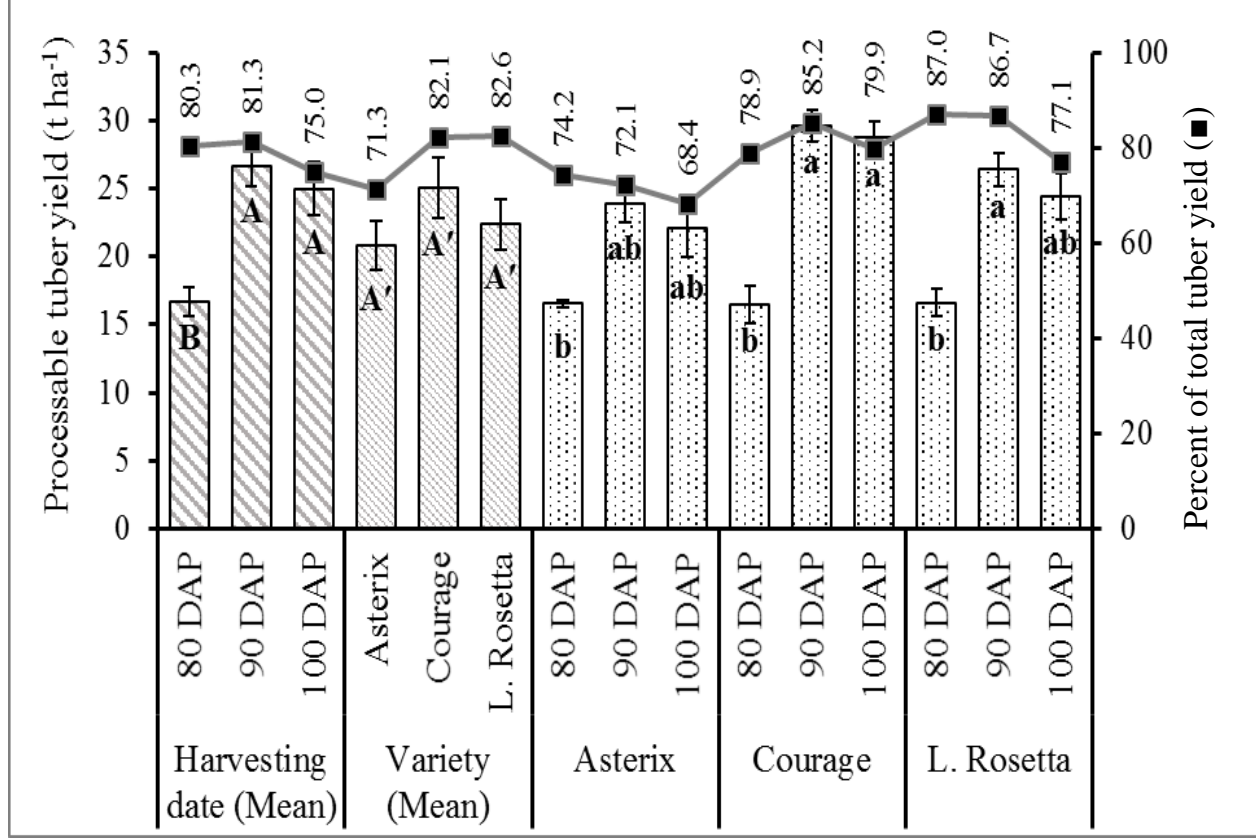

Fig. 2. Processable tuber yield of potatoes as influenced by varieties under different harvesting dates. Vertical bass represent standard error $( \pm \mathrm{SE})$ of four replicates.

* Values in a column with different capital letter(s) are significantly different at $\mathrm{P}=0.05$ by DMRT.

\$ Values in a column with different prime-marked capital letter(s) are significantly different at $\mathrm{P}=0.05$ by DMRT.

‡ Values in a column with different small letters denote interaction effect and are significantly different at $\mathrm{P}=0.05$ by DMRT.

\section{Total tuber yield}

Harvesting time had significant effect on total tuber yield and increased with the crop maturity but the varieties did not show any statistical difference (Fig. 3, Table 1). The increment was significant from 80 to 90 DAP but in 100 DAP; it was insignificant. The interaction effect of Variety $\times$ Harvesting dates gave lowest tuber yield at $80 \mathrm{DAP}$ harvest in all three processing potato varieties. The highest total tuber yield was recorded in variety Courage $\left(35.97 \mathrm{t} \mathrm{ha}^{-1}\right)$ at 100 DAP (Fig. 3).

Among the varietal means, although yield didn't vary significantly, Courage showed the highest tuber yield (30.54 tha-1) followed by Asterix $\left(29.23 \mathrm{t} \mathrm{ha}^{-1}\right)$ and Lady Rosetta (27.09 $\mathrm{t} \mathrm{ha}^{-1}$ ) (Fig. 3). 


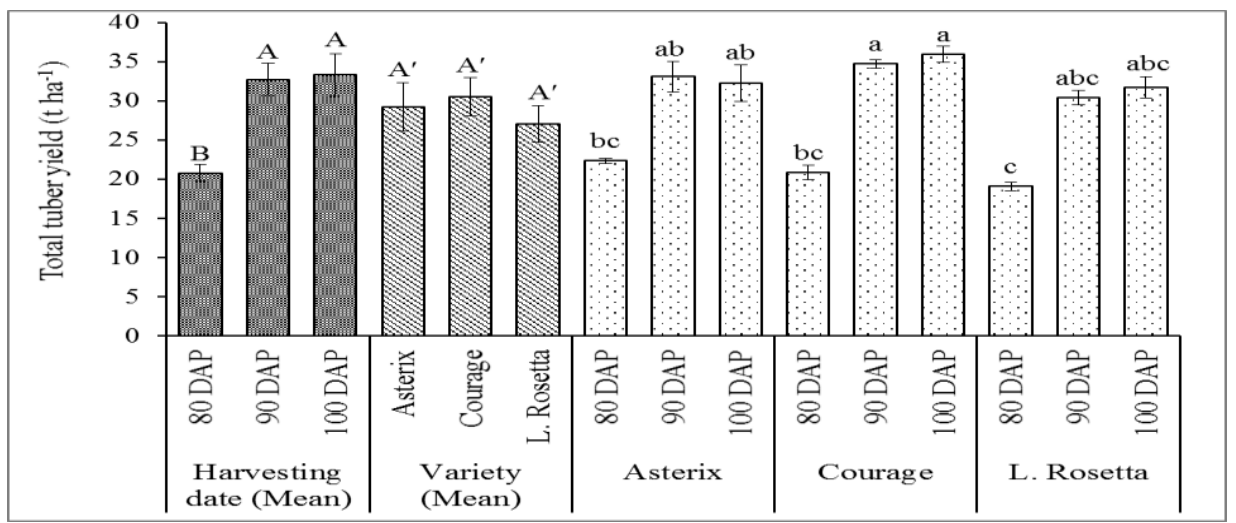

Fig. 3. Total tuber yield of potatoes as influenced by varieties under different harvesting dates. Vertical bass represent standard error $( \pm \mathrm{SE})$ of four replicates.

Values in a column with different capital letter(s) are significantly different at $\mathrm{P}=0.05$ by DMRT.

中 Values in a column with different prime-marked capital letter(s) are significantly different at $\mathrm{P}=0.05$ by DMRT.

$¥$ Values in a column with different small letters denote interaction effect and are significantly different at $\mathrm{P}=0.05$ by DMRT

Considering the mean value of harvesting dates, 100 DAP harvest gave the highest tuber yield $\left(33.31 \mathrm{t} \mathrm{ha}^{-1}\right)$ followed by $90\left(32.76 \mathrm{t} \mathrm{ha}^{-1}\right)$ and 80 DAP harvest $\left(20.78 \mathrm{t} \mathrm{ha}^{-1}\right)$ (Fig. 3). The higher yield at $100 \mathrm{DAP}$ harvest compared to 80 DAP harvest might be result of considerable accumulation of dry matter in the tubers after the linear phase of bulking (Gregory, 1956). Because an early harvest, even at an advanced stage of the crop, leads to significant reductions in the percentage of large tubers and the tuber specific gravity (Silva, 2004). Although, many tubers may be initiated during the first four to six weeks of growth, only a fraction of these tubers actually achieves commercial size (greater than $30 \mathrm{~mm}$ diameter). The duration and rate of tuber bulking vary among varieties and depend on environmental condition. Here, 90 DAP harvest can be considered as good for total tuber production compared to 100 DAP since there are no significant differences in between them.

\section{Dry matter content $(\%)$}

The dry matter content in potato tuber was significantly influenced by the variety and different harvesting dates. Dry matter (\%) was increased up to 90 DAP harvest and thereafter decreased in all three potato varieties (Fig. 4). The highest dry matter content (26.37\%) was found in Lady Rosetta at 90 DAP, which was statistically similar with 100 DAP harvest $(25.55 \%)$ in the same variety, and it was significantly higher than Asterix (21.91\%) and Courage (23.93\%). In all 3 varieties, the highest dry matter content was attained at 90 DAP harvest 
compared to 80 and 100 DAP (Fig. 4). Moreover, the mean value of harvesting dates also showed that, $90(24.07 \%)$ DAP harvest gained significantly higher dry matter (\%) than 80 (21.71\%) and 100 (22.27\%) DAP harvest (Fig. 4).

Varietal means of dry matter content, irrespective of harvesting time, was found significantly higher in Lady Rosetta (24.87\%) as compared to Asterix (20.02\%) and Courage (23.14\%) (Fig. 4). The results indicate that variety Lady Rosetta can be preferred as suitable variety and 90 DAP harvest can be optimum to get higher dry matter (\%). Dry matter is an index of better processing quality, as it results into lesser oil absorption, less frying time (Pavlista and Ojala, 1997) and better textured products (Genet, 1992) associated with high fat absorption at frying (Araújo et al. 2016). And this biomass accumulation can be influenced by various factors, especially by the cultivar, date of harvest and location (Marwaha et al., 2005). Though early harvesting of potato tuber gives economic support to the farmers but it affects the quality. Tuber harvested at increased maturity stage contain maximum dry matter than immature ones (Misra et al., 1993). Solaiman et al. (2015) recorded higher (21.72\%) dry matter at 110 DAP compared to 80 DAP (16.94\%) while a slight decrease in dry matter accumulation at later stage of maturity was observed earlier (Wubr, 1978) that resembles the present findings.

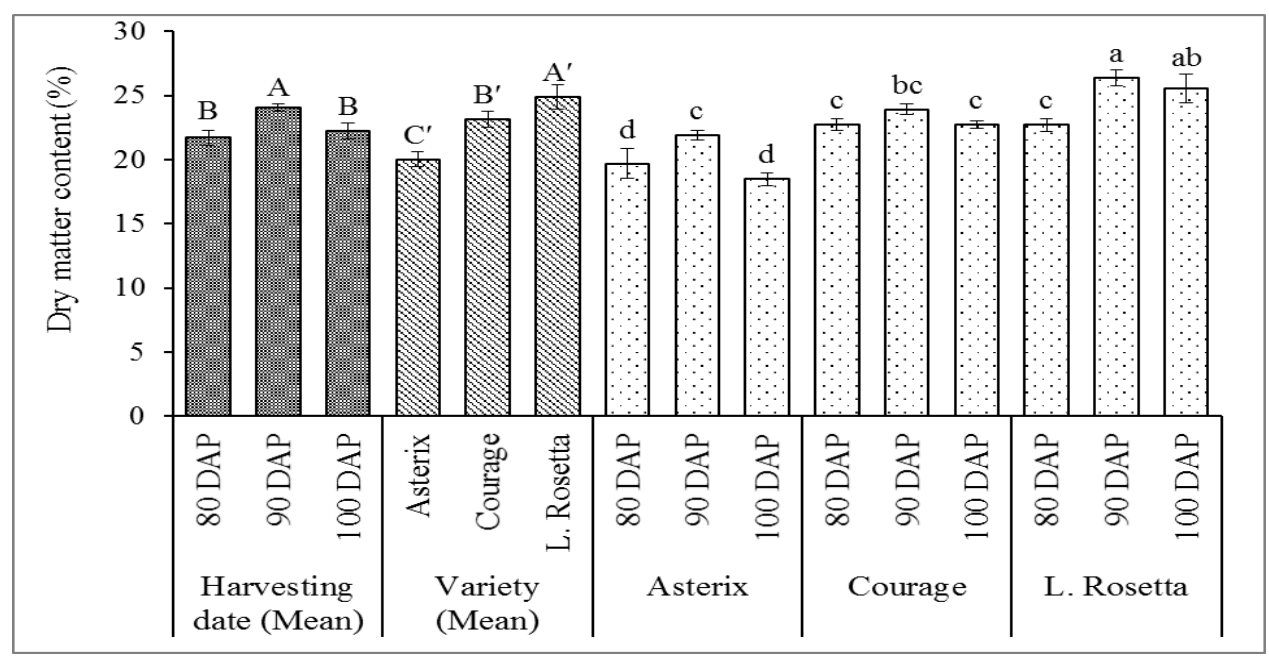

Fig. 4. Dry matter content in potatoes as influenced by varieties under different harvesting dates. Vertical bass represent standard error $( \pm \mathrm{SE})$ of four replicates.

\& Values in a column with different capital letter(s) are significantly different at $\mathrm{P}=0.05$ by DMRT.

* Values in a column with different prime-marked capital letter(s) are significantly different at $\mathrm{P}=0.05$ by DMRT.

$\ddagger$ Values in a column with different small letters denote interaction effect and are significantly different at $\mathrm{P}=0.05$ by DMRT. 


\section{Specific gravity}

Specific gravity is an important factor for maintaining quality tuber and is directly associated with the dry matter content (Haase, 2003; Pedreschi and Moyano, 2005). Changes in specific gravity between harvesting dates is insignificant for all the varieties (interaction effect) in the present finding (Fig. 5). 90 DAP harvest gave higher specific gravity in case of all varieties.

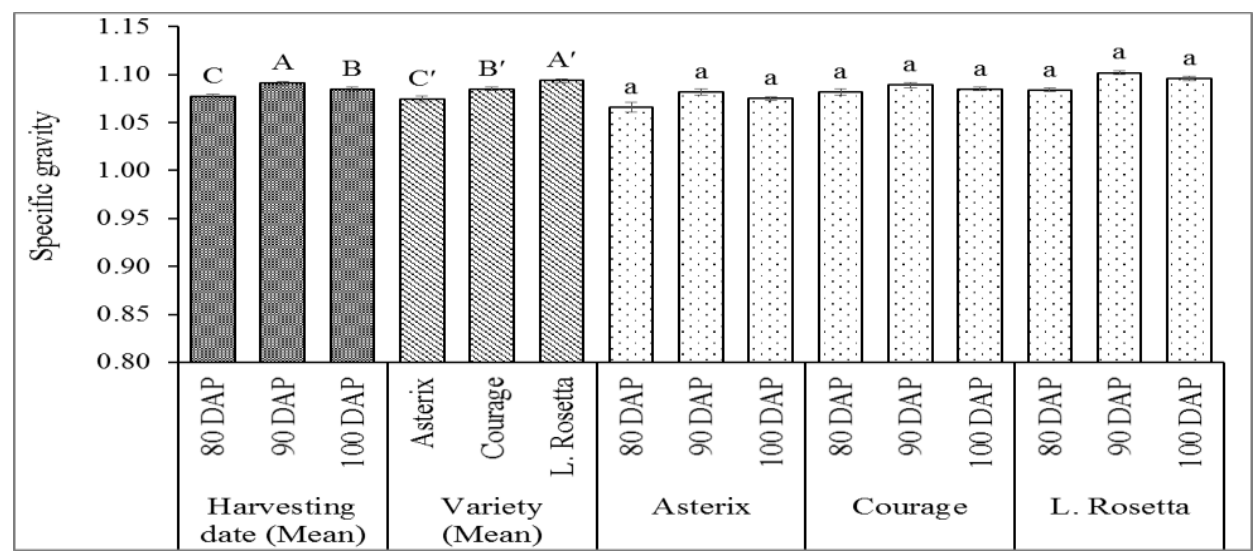

Fig. 5. Specific gravity of potatoes influenced by varieties under different harvesting dates. Vertical bass represent standard error $( \pm \mathrm{SE})$ of four replicates.

${ }^{中}$ Values in a column with different capital letter(s) are significantly different at $\mathrm{P}=0.05$ by DMRT.

\$ Values in a column with different prime-marked capital letter(s) are significantly different at $\mathrm{P}=0.05$ by DMRT.

₹ Values in a column with different small letters denote interaction effect and are significantly different at $\mathrm{P}=0.05$ by DMRT

Variety Lady Rosetta (1.102) gave the highest specific gravity at 90 DAP followed by Courage (1.089) and Asterix (1.082). The varietal mean values exhibited that Lady Rosetta (1.094) had significantly higher specific gravity (1.094) as compared to Courage (1.085) and Asterix (1.0741) (Fig. 5). Counting the harvest mean, 90 DAP harvest gave significantly higher specific gravity compared to 100 (1.094) and 80 (1.074) DAP harvest (Fig. 5).

With increasing harvesting time i.e from 80 to 110 DAP, significantly increased specific gravity (1.050 to 1.085) was also reported by Solaiman et al. (2015) and Marwaha (1998). But a slight decrease in specific gravity at 100 DAP harvest was found that could be the result of reduced dry matter accumulation at the later stage. From the above mentioned results it can be said that 90 DAP harvest can be most suitable harvest date to get higher specific gravity in potatoes. Because higher specific gravity is an indication of higher dry matter content and lower reducing sugar content in potato tubers (Schippers, 1976; Salamoni et al., 2000) 
so, investigation of specific gravity in tubers for processing purposes could play a vital role as a preliminary indication of good quality potatoes.

\section{Starch content}

The effect of variety $\times$ harvesting dates on starch content of the potatoes showed an increase up to $90 \mathrm{DAP}$ in all the three varieties but this increment was significant in Courage and Asterix also (Fig. 6). Afterwards it significantly increased in variety Asterix and declined in Courage and Lady Rosetta. Variety Courage and Lady Rosetta gave the highest starch content at 90 DAP harvest but in Asterix, the highest starch content was attained at 100 DAP. The highest starch content was found in Courage (118.56 $\left.\mathrm{mg} \mathrm{g}^{-1} \mathrm{FW}\right)$ at 90 DAP followed by Asterix (114.51 $\left.\mathrm{mg} \mathrm{g}^{-1} \mathrm{FW}\right)$ at $100 \mathrm{DAP}$ and Lady Rosetta $\left(112.93 \mathrm{mg} \mathrm{g}^{-1} \mathrm{FW}\right)$ at 90 DAP harvest (Fig. 6).

Among the varieties, the highest starch content was observed in Lady Rosetta (111.75 $\mathrm{mg} \mathrm{g}^{-1} \mathrm{FW}$ ), which was closely followed by Courage (111.17 $\mathrm{mg} \mathrm{g}^{-1}$ FW). The minimum starch content was recorded in Asterix $\left(103.95 \mathrm{mg} \mathrm{g}^{-1} \mathrm{FW}\right)$ (Fig. 6). Among the harvest means, 100 DAP gave the highest mean starch content $\left(111.47 \mathrm{mg} \mathrm{g}^{-1} \mathrm{FW}\right)$ followed by 90 DAP $\left(110.15 \mathrm{mg} \mathrm{g}^{-1} \mathrm{FW}\right)$ and 80 DAP (105.25 $\mathrm{mg} \mathrm{g}^{-1} \mathrm{FW}$ ) harvest (Fig. 6). Noda et al. (2004) found a manifest increase (18-20\%) in starch content at late maturity whereas a range of 82.90$101.0 \mathrm{mg}$ starch $\mathrm{g}^{-1}$ fresh potato sample was recorded by Al-Meraj et al. (2017) that supports the finding of the study.

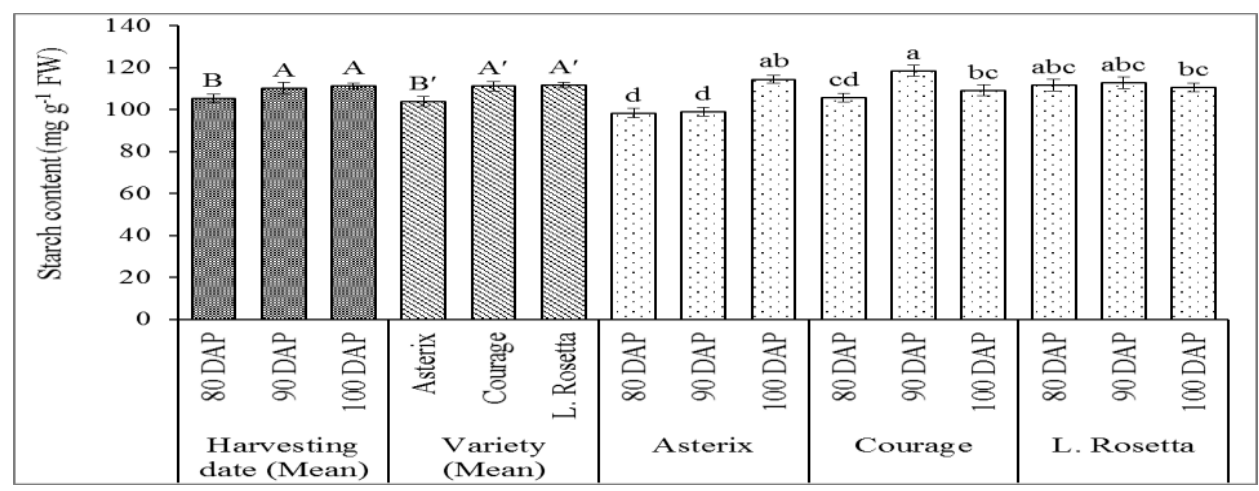

Fig. 6. Starch content of potatoes as influenced by varieties under different harvesting dates. Vertical bass represent standard error $( \pm \mathrm{SE})$ of four replicates.

${ }^{\phi}$ Values in a column with different capital letter(s) are significantly different at $\mathrm{P}=80.05$ by DMRT.

\& Values in a column with different prime-marked capital letter(s) are significantly different at $\mathrm{P}=0.05$ by DMRT.

$\neq$ Values in a column with different small letters denote interaction effect and are significantly different at $\mathrm{P}=0.05$ by DMRT. 
As we know, higher starch content is desired for quality product because starch comprises the largest part of dry matter, it has direct influence on technological quality, especially with regard to the texture of the processed products (Kadam et al., 1991). So to obtain higher amount of starch content, 90 DAP harvest can be optimum harvesting date in case of variety Courage and Lady Rosetta.

\section{Conclusion}

The maximum dry matter content, specific gravity, starch content and processable tuber yield were recorded at 90 DAP harvest. Among the varieties, the highest yield and the maximum processing quality were noted in Lady Rosetta followed by Courage. Therefore, Lady Rosetta and Courage as processing variety and 90 DAP harvest can be recommended for processing purpose.

\section{Acknowledgement}

The research was funded by a grant awarded to Mohammed Mohi-Ud-Din by Research Management Committee (RMC), Bangabandhu Sheikh Mujibur Rahman Agricultural University, Gazipur- 1706, Bangladesh. The authors are greatful to the RMC for help rendering during this study.

\section{References}

Al-Meraj, S. M. Z., M. Mohi-Ud-Din, A. K. M. A. Islam and T. K. Ghosh. 2017. Evaluation of potato genotypes for processing quality attributes. Annals of Bangladesh Agriculture. 21(1 \& 2): 99-110.

Araújo, T. H., J. G. Pádua, M. H. Spoto, V. D. Ortiz, P. L. Margossian, C. T. Dias, and P. C. Melo. 2016. Productivity and quality of potato cultivars for processing as shoestrings and chips. Horticultura Brasileira. 34(4): 554-560.

BBS. 2017. Yearbook of Agricultural Statistics-2017. Bangladesh Bureau of Statistics, Statistics and Informatics Division (SID). Ministry of Planning. $29^{\text {th }}$ series.

Buono, V., A. Paradiso, F. Serio, M. Gonnella, L. De Gara, and P. Santamaria. 2009. Tuber quality and nutritional components of "early" potato subjected to chemical haulm desiccation. Journal of food composition and analysis. 22(6): 556-562.

Genet, R. A. 1992. Potatoes-the quest for processing quality. In Proceedings of the Agronomy Society of New Zealand. 22: 3-7.

Gregory, L. E. 1956. Some factors for tuberization in the potato plant. American Journal of Botany. 43(4): 281-288.

Haase, N. U. 2003. Estimation of dry matter and starch concentration in potatoes by determination of under-water weight and near infrared spectroscopy. Potato research. 46(3-4): 117-127.

Hamouz, K., J. Lachman, P. Dvorák and V. Pivec. 2005. The effect of ecological growing on the potatoes yield and quality. Plant Soil and Environment. 51(9): 397. 
Herrman, T. J., S. L. Love, B. Shafii and R. B. Dwelle. 1996. Chipping performance of three processing potato cultivars during long-term storage at two temperature regimes. American Potato Journal. 73(9): 411-425.

Kadam, S. S., S. S. Dhumal and N. D. Jambhale. 1991. Structure, nutritional composition, and quality. Potato: production, processing, and products. CRC, Boca Raton. 9: 35.

Kang, Y. Y., S. R. Guo, J. Li and J. J. Duan. 2009. Effect of root applied 24epibrassinolide on carbohydrate status and fermentative enzyme activities in cucumber (Cucumis sativus L.) seedlings under hypoxia. Plant Growth Regul. 57(3): 259-269.

Karim, M. R., M. M. Hanafi, S. M. Shahidullah, A. H. M. A. Rahman, A. M. Akanda and A. Khair. 2010. Virus free seed potato production through sprout cutting technique under net-house. African Journal of Biotechnology. 9: 36.

Kumar, M., L. K. Baishya, D. C. Ghosh and V. K. Gupta. 2011. Yield and quality of potato (Solanum tuberosum) tubers as influenced by nutrient sources under rainfed condition of Meghalaya. Indian Journal of Agronomy. 56(3): 260.

Lisińska, G. 2006. Technological and nutritive value of the Polish potato cultivars. Zeszyty Problemowe Postepow Nauk Rolniczych. 511: 81-91.

Lulai, E. C., and P. H. Orr. 1979. Influence of potato specific gravity on yield and oil content of chips. American Potato Journal. 56(8): 379-390.

Marwaha, R. S., Pandey, S. K., Singh, S. V., \& Khurana, S. P. (2005). Processing and nutritional qualities of Indian and exotic potato cultivars as influenced by harvest date, tuber curing, pre-storage holding period, storage and reconditioning under short days. Advances in Horticultural Science. 130-140.

Mathur, A. 2003. Studies on phosphorylation status of starch in potato tubers (Solanum tuberosum L.) (Doctoral dissertation, MSc. Thesis, Department of Biotechnology and Environmental Sciences, Thapar Institute of Engineering and Technology, Patiala).

Misra, J. B., S. K. Anand and P. Chand, 1993. Changes in processing characteristics and protein content of potato tubers with crop maturity. Journal of Indian Potato Association. 20: 150-154.

Murniece, I., D. Karklina, R. Galoburda and M. Sabovics. 2010. Reducing sugar content and colour intensity of fried Latvian potato varieties. Latvijas Lauksaimnieci ${ }^{-}$bas Universita ${ }^{-}$te-Raksti. 24: 20-30.

Muthuraj, R., G. Ravichandran, K. S. K. Prasad and S. Singh. 2005. Effect of planting date on seed size tuber yield of potato in Nilgiris. Potato Journal. 32: 3-4.

Noda, T., S. Tsuda, M. Mori, S. Takigawa, C. Matsuura-Endo, K. Saito, and H. Yamauchi. 2004. The effect of harvest dates on the starch properties of various potato cultivars. Food Chemistry. 86(1): 119-125.

Pádua, J. G., T. H. de Araújo, E. L. do Carmo, P. L. Margossian and S. G. Pereira. 2012. Cultivares de batata para o mercado segmentado. Revista Raízes e Amidos Tropicais. 8(1): 36-46.

Patel, C. K., P. T. Patel and S. M. Chaudhari. 2008. Effect of physiological age and seed size on seed production of potato in North Gujarat. Potato Journal. 35: 1-2. 
Pavlista, A. D., and J. C. Ojala. 1997. Potatoes: Chip and French fry processing. Processing Vegetables, Science and Technology. Lancaster: Technomic Publishing, Inc. 237-284.

Pedreschi, F., and P. Moyano, 2005. Effect of pre-drying on texture and oil uptake of potato chips. LWT-Food Science and Technology. 38(6): 599-604.

Pedreschi, F., P. Moyano, K. Kaack and K. Granby. 2005. Color changes and acrylamide formation in fried potato slices. Food Research International. 38(1): 1-9.

Rommens, C. M., R. Shakya, M. Heap and K. Fessenden. 2010. Tastier and healthier alternatives to French Fries. Journal of Food Science. 75(4): 109-115.

Rytel, E. 2004. Influence of potato maturity on changes of non-starch polysaccharides and lignin content in tubers. Zeszyty Problemowe Postepow Nauk Rolniczych. 500: 295-303.

Salamoni, A. T., A. D. S. Pereira, J. Viégas, Â. D. Campos and C. S. D. A. Chalá. 2000. Variance of genetic reducing sugars and dry matter and their correlations with agronomic traits in potatoes. Pesquisa Agropecuária Brasileira. 35(7): 1441-1445.

Schippers, P. A. 1976. The relationship between specific gravity and percentage dry matter in potato tubers. American Potato Journal. 53(4): 111-122.

Silva, L. A. S. 2004. Duração do ciclo vegetativo e sua relação com o potencial produtivo de genótipos de batata (Doctoral dissertation, Universidade Federal de Lavras.).

Solaiman, A. H. M., T. Nishizawa, T. S. Roy, M. Rahman, R. Chakraborty, J. Choudhury, and M. Hasanuzzama. 2015. Yield, Dry Matter, Specific Gravity and Color of Three Bangladeshi Local Potato Cultivars as Influenced by Stage of Maturity. Journal of Plant Sciences. 10(3): 108-115.

Wurr, D. C. E., J. N. Bean, and E. J. Allen. 1978. Effects of variety and date of harvest on the tuber dry-matter percentage of potatoes. The Journal of Agricultural Science. 90(3): 597-604.

Zgórska, K., and A. Frydecka-Mazurczyk. 2002. Normy i wymagania jakościowe ziemniaków jadalnych i do przetwórstwa spożywczego. W: Produkcja i rynek ziemniaków jadalnych. Red. J. Chotkowski. Wyd. Wieś Jutra, Warszawa. 183-192. 
